\title{
Lambang Dewate Nawasange Sebagai Wujud Pengaruh Peradaban Majapahit Di Bali
}

\author{
I Nyoman Lodra \\ Pendidikan Seni Rupa dan Kerajinan, FBS, Pascasarjana S.2 Pendidikan Seni Budaya \\ Univrsitas Negeri Surabaya. Kode Pos 60213.Indonesia \\ nyomanlodra@unesa.ac.id
}

Lambang "Dewate Nawesange" sebagai gambaran visual 9 dewa manifestasi Ide Sang Hyang Widhi yang mengusai sembilan penjuru mataangin merupakan bagian dari nilai ajaran Agama Hindu. Oleh umat Hindu di Bali lambang tersebut termasuk di sakralkan dan digunakan sebagai sarana/prasarana upacara serta wujudnya dibuat dalam bentuk relief, gambar (kober, umbul-umbul), "sate gelar sange". Kajian visual lambang Dewate Nawesange tersebut ada kesamaan serta kuat dugaan telah terjadi akulturasi dengan lambang Surya Majapahit Trowulan Jawa Timur. Para ahli menyebut gambar lambang Surya Majapahit yang tersimpan di Musium Trowulan tersebut sebagai lambang dari kerajaan Majapahit. Fokus pembahasan: bagaimana bisa terjadi kemiripan atau kesamaan bentuk visual antara lambang Surya Majapahit dengan lambang "Dewate Nawesange"?. Tujuan: mendiskripsikan faktor-faktor yang mempengaruhi terjadi kemiripan atau kesamaan bentuk visual antara lambang Surya Majapahit dengan lambang Dewate Nawesange. Metode penelitian: deskriptif kualitatif menguraikan faktor-faktor yang menyebabkan terjadi kesamaan dari dua lambang tersebut, dengan kajian teori semiotik, teori etnografi, ikonografi, dan teori pertukaran sosial. Sumber data: dokumen lambang Surya Majapahit yang ada di Musium Trowulan dan lambang "dewate nawesange" yang berkembang di Bali. Hasil kajian dan analisis lambang Surya Majapahit dan lambang Dewate Nawesange ditemukan telah terjadi akulturasi ajaran "sekte-sekte" di Bali dengan lambang Surya Majapahit. Temuan: lambang "dewate nawesange" sebagai bentuk akulturasi dari nilai ajaran "sekte-sekte" di Bali terjadi pada saat kekuasaan kerajaan Majapahit.

Kata kunci: akulturasi, lambang, dewate nawesange, sekte, surya majapahit

\section{The Symbol Of Dewate Nawasange As A Manifestation Of The Influence Of Majapahit Civilization In Bali}

The symbol of Dewate Nawesange, a visual manifestation of Sang Hyang Widhi in the form of 9 gods that control the nine directions of the wind, represents a value from Hindu teachings. To Balinese Hindus, this sacred symbol is used as a ceremonial medium in the form of a relief, picture (flag or banner), "sate gelar sange". A visual study of the Dewate Nawesange symbol shows similarities and probable acculturation with the symbol of Surya Majapahit in Trowulan, East Java. Experts say the image of Surya Majapahit in Trowulan Museum symbolizes the Majapahit Kingdom. The focus of this study is to discover how there could be similarities in the visual forms of the symbols of Surya Majapahit and Dewate Nawesange. The goal is to describe the factors that influenced the similarities in the visual form of these two symbols. The qualitative descriptive research method analyzes the factors that caused the similarities between these two symbols, through a study of semiotic theory, ethnographic theory, iconography, and social exchange theory. The data source is documents of the Surya Majapahit symbol in Trowulan Museum and the Dewate Nawesange symbol in Bali. The results of the study and analysis of the Surya Majapahit and Dewate Nawesange symbols shows evidence of acculturation of the teachings of Balinese "sects" with the Surya Majapahit symbol. The findings of the study show that the Dewate Nawesange symbol, a form of acculturation of the moral values of certain "sects" in Bali, occurred during the Majapahit era.

Keywords: acculturation, symbol, dewate nawesange, sect, surya majapahit

Proses Review : 1 - 18 April 2019, Dinyatakan Lolos: 22 April 2019 


\section{PENDAHULUAN}

\section{Latar belakang}

Bekas kekuasaan kerajaan Majapahit di seluruh Nusantara masih dapat ditemukan dalam bentuk nilai-nilai budaya berupa adat-istiadat, keyakinan, kepercayaan, budaya, dan aterfak (relief, patung, pahatan, gambar) seperti halnya di Bali. Nilai-nilai budaya yang masih lestari dan berkembang seperti peringatan hari "Sugihan Jawa", hari Galungan, Kuningan, kegiatan ritual lainnya termasuk pengenalan konsep lambang "dewate nawesange". Selain itu juga ada dalam bentuk bangunan "Pure Kayangan Tiga", sistem pengairan (subak), dan nama untuk para dewa-dewi. Bekas kejayaan kerajaan Majapahit di Bali tersebut tidak murni, namun bentukan dari hasil akulturasi antara budaya lokal (budaya Bali) dengan budaya pendatang (Majapahit). Muncul budaya yang mencerminkan nilai-nilai dari kedua budaya tersebut sebagai dampak dari proses kristisasi terhadap budaya lokal. Peristiwa akuluturasi tersebut diperkuat oleh pemikiran Suyono (1995:2018) sebagai pengambilan atau penerimaan satu atau beberapa unsur budaya yang saling berhubungan. Juga sejalan dengan pemikiran Dwi Hayudiarto (2005:37) munculnya sekelompok orang asing yang dihadapkan dengan budaya lokal lamakelamaan diterima tanpa menghilangkan kepribadian budaya lokalnya.

Berawal dari kekalahan kerajaan Bali oleh Ratu Tribuanatunggadewi dari kerajaan Majapahit dengan Patih Gajah Mada berdampak terjadi perubahan pada tatanan kehidupan masyarakat khususnya dalam berkeyakinan dan beragama. Pascakekuasaan Majapahit pelaksanaan tugas dipercayakan pada Patih Gajah Mada dan kebijakannya menunjukan orang-orang untuk untuk mengisi kekuasaan di Bali seperti: Arya Kutawaringi, Arya Kenceng, Arya Belog, Arya Sentong, Arya Kenuruhan, dan Singa Sardula. Hegomoni kekuasaan dari penguasa baru tersebut terjadi perubahan dan kemajuan pada kehidupan sosial, ekonomi, budaya, termasuk dalam kegiatan agama Hindu, dan kepercayaan di Bali. (https://historia.id/kuno/articles/ majapahit-menaklukkan-bali-DbeEG).

Pada tahun 1350-1389 kerajaan Majapahit mencapai kejayaan dan kekuasaan dipegang oleh prabu Hayam Wuruk. Perhatian kerajaan pada kegiatan keagamaan sangat intens, para agamawan, para rsi mempunyai peranan penting. Agama Siwa dan Budha menjadi agama resmi kerajaan sampai akhir tahun 1447, termasuk pembenahan kehidupan kepercayaan "sekte-sekte"di Bali. Para rohani, rsi dari kerajaan Majapahit terus-menerus melakukan pembenahan seperti pembuatan irigasi, "pure" (tempat ibadah), pengenalan konsep agama Hindu, dan termasuk konsep "Dewata Nawesange". Dalam masyarakat kedatangan penguasa baru ini munculkan pro-kontra terbelah menjadi dua kelompok. Kelompok masyarakat yang menolak dan tidak terima menyingkir masuk kedaerah-daerah pegunungan yang kemudian mereka dikenal dengan sebutan mas- yarakat "Baliage" (bali mule). Kelompok yang menerima dan tunduk pada penguasa baru tinggal di daerah-daerah yang dekat dengan pemerintahan. Kelompok masyarakat yang dekat dengan penguasa dikenal dengan sebutan "Bali Majapahit". Kedua kelompok masyarakat tersebut memberikan warna yang berbeda dalam melaksanakan kegiatan agama Hindu di Bali. Dampak kedatangan tokoh-tokoh rohaniawan dari kerajaan Majapahit memberikan suasana baru pada kehidupan "sekte-sekte", dan ketertiban dalam beragama Hindu. Hal tersebut dikarenakan raja Majapahit pada waktu itu beragama Siwasiddhanta, dan bergama Budha Mahayana diman kedua ajaran tersebut ada kemiripan dengan kepercayaan yang berkembang di Bali. Adanya kesamaan dan kemiripan dari ajaran-ajaran dengan aliran kepercayaan di Bali tentunya lebih mudah terjadi akulturasi. (https://history1978.wordpress. com/2010/04/07/agama-pada-masa-majapahit).

Menurut Osrifoel tahun 1478 di masa pemerintahan Girindrawardhana kerajaan Majapahit rutuh di akibat serangan kerajaan Islam Demak. Namun menurut Djafar pada tahun 1519 saat kekuasaan Pati Unus, kerajaan majapahit sudah kehilangan kedaulatan (https://historia.id/kuno/ articles/penyebab-lain-keruntuhan-majapahit-DEZ1x). Runtuh kerajaan Majapahit menyebabkan terjadi eksodus tokoh-tokoh rohaniawan Hindu, menuju ke arah Timur dengan tujuan Bali. Alasannya karena kehidupan masyarakatnya saat taat dan tertib dalam pelaksanaan agama Hindu.

Kehadiran tokoh rohaniawan dari Majapahit pada gelombang ke dua lebih memantapkan aktivitas Agama Hindu di Bali. Di ketahui sebelum masuknya pengaruh budaya Majapahit pasca perang antara kerajaan Bali dengan kerajaan Majapahit telah berkembang aliran atau sekte-sekte seperti Siwaistis, Waisnawe, Indra, Bairawa, dan kepercayaan. Salah satu jejak peninggalan dari kekuasaan Majapahit sampai sekarang masih dilaksanakan dan disakralkan adanya lambang "dewate nawesange". Pada lambang tersebut tampak adanya pembenahan konsep dalam bergama Hindu seperti halnya pengenalan fungsi, artibiut tentang dewa-dewa penguasa alam jagat raya yang dibuat dalam bentuk lambang Dewate Nawesange. Lambang "dewate nawesange" atau 9 dewa sebagai manifestasi dari Ide Sang Hyang Widhi pada wujud visual dibuat dalam bentuk melingkar terbagi 8 ruang ditambah 1 ruang ada ditengah dan masing-masing digambarkan wujud dewa-dewa lengkap dengan artibiut senjata dipinggir lingkaran ada goresan mengesankan sinar matahari.

Lambang "dewate nawesanga" sebagai bentuk reproduksi budaya dengan kemunculan karakteristik budaya yang didatangi dan budaya pendatang. Reproduksi budaya merupakan proses presentasi budaya asal terhadap budaya yang didatangi atau lingkungan baru. Proses reproduksi budaya adalah proses aktif yang melatarbelakangi seseorang melakukan adaptasi terhadap budaya yang berbeda. 
Proses reproduksi budaya dapat terjadi melalui mobilitas sosial yang dilakukan oleh seseorang atau kelompok masyarakat. Mobilitas sosial tersebut terjadi perubahan dalam wilayah tempat tinggal, latar belakang budaya, yang akhirnya menjadi warna bagi budaya, seperti halnya lambang "dewate nawesange" adanya cerminan budaya lokal dan budaya Majapahit.

Mengkaji dan mengungkap lambang "dewate nawesange" sebagai jejak peninggalan budaya Majapahit dengan menggunakan beberapa teori seperti berikut. Teori ikonografi (ilmu yang mempelajari tentang seni gambar) tampak elemen-elemen estetik dari lambang "dewe nawesange" ada elemen-elemen estetik surya majapahit. Pada konsep perwujudan lambang tersebut tampak nilai ajaran "sekte-sekte" yang berkembang sebelum masuk pengaruh budaya Majapahit. Teori ikonografi dapat mengungkap konsep lambang "dewate nawesange" mulai dengan artibiut, figur, ornamen yang mencerminkan konsep-konsep perpaduan dari ajaran "sekte-sekte" yang telah berkembang sebelum masuknya pengaruh Hindu di Bali dengan lambang Surya Majapahit. Teori semiotik dapat mengungkap lambang "dewate nawesange" sebagai simbol alam semesta (makrokosmos) dan masing-masing figur dewa-dewa di tempat 9 penjuru mataangin berfungsi sebagai penguasa, menjaga keamanan wilayah serta dimaknai keamanan akan tetap terjaga. Oleh Geertz (1973) etnografi sebagai pendekatan emperis dan teoritis dengan tujuan untuk dapat mendeskripsikan secara mendalam tentang budaya dilapangan secra intesip mengenai kehidupan sosial masyarakat. Dalam hal ini teori etnografi bisa membuka kehidupan sosial masyarakat terhadap lambang "dewate nawesange" oleh umat Hindu di Bali diyakini memiliki kekuatan magis bisa menjaga keseimbangan jagat alam semesta serta sangat di sakralkan. Selain itu pula lambang tersebut memiliki makna spritual digunakan dalam upacara pancayadnya, difunsikan untuk "ider-ider", kober, umbul-umbul, "sate gelar sange" juga bernilai estetik dijadikan ekspresi dalam berkesenian dalam seni lukis, patung, dan relief. Kajian semiotik (Roland Barthes:1915-1980), pada lambang Dewate Nawesange dan lambang Surya Majapahit yang memiliki beberapa kesamaan oleh Peirce disebut dengan segitiga atau triangle meaning yakni tanda (simbol) yang berbentuk fisik karna adanya kesepakatan, objek, mengacu pada kedua lambang dan interpretat konteks pada kehidupan sosial masyarakat Bali.

Hasil analisis dengan menggunakan teori-teori di atas lambang "dewate nawesange" diketahui sebagai reproduksi budaya melalui proses akulturasi dari ajaran"sekte-sekte" di Bali dengan lambang Surya Majapahit. Sangat memungkinkan proses akulturasi tersebut terjadi pada saat kerajaan Bali dipimpin oleh Raja Sri Astasura Bumi Banten. Hal tersebut diperkuat penelitian Aulia Vera Rozida, 2010, Pola Komunikasi Masyarakat Suku Nuhatan sebagai Dampak Akulturasi Budaya, Fakultas Ilmu Budaya universitas Udayana (https://jurnal.unitri.ac.id/ index.php/reformasi/article/view/10) yang membahas masalah dampak dari akulturasi pada individu, kelompok masyarakat suku Nurhatan. Begitu pula penelitian Dwi Woro.R, 2008, Wayang Cina di Jawa sebagai Wujud Akulturasi Budaya dan Perekat Negara Kesatuan Republik Indonesia, yang membahas Masyarakat cina berimigrasi ke pulau Jawa dan telah melahirkan suatu tradisi dan budaya baru yaitu budaya Cina-Jawa sebagai bentuk perkawinan dua budaya yaitu budaya Cina dan budaya Jawa, sebagai bentuk akulturasi. Suyono (1995:2018) dan Dwi Hayudiarto (2005:37) dalam pengambilan atau penerimaan satu atau beberapa unsur budaya disebut sebagai akulturasi. Secara habitus masyarakat menerima konsep lambang "dewate nawesange" merupakan bagian dari pengakulturasi lambang surya majapahit dengan nilai-nilai ajaran "sekte-sekte" sebelum masuk pengaruh hindu di Bali. (https:// history1978.wordpress.com/2010/04/07/agama-pada-masa-majapahit/).

\section{Tujuan Penelitian}

Secara spesipik tujuan penelitian ini menambah pengetahuan tentang lambang "dewate nawesange" sebagai sebuah produk hasil akulturasi antara ajaran "sekte-sekte yang sebelumnya sudah berkembang di Bali dengan lambang Surya Majapahit. Di samping itu pula penelitian ini bertujuan untuk menemukan makna dari akulturasi budaya Bali Kuno dengan budaya dari masa kejayaan kerajaan Majapahit. Adapun hasil penelitian berkontribusi atau memberi sumbangan keilmuan terkait dengan pengetahuan telah terjadi akulturasi antara budaya lokal dalam posisi terhegomoni dengan budaya penguasa dari kerajaan Majapahit. Di samping itu pula paling tidak lambang "dewate nawesange" dapat dijadikan tonggak sejarah kemantapan dan intensipnya kehidupan Agama Hindu di Bali. Latarbelakang keberadaan lambang tersebut secara habitus diterima dan berkembang sebagai bentuk nilai ajaran Agama Hindu di Bali penting untuk dilakukan penelitian mendalam dengan judul: Lambang "Dewate Nawesange" sebagai wujud pengaruh peradaban Majapahit di Bali.

\section{a. Lambang Surya Majapahit}

Yang menarik diantara koleksi Musium Trowulan Mojokerto Jawa Timur adalah pahatan Surya Majapahit yang ditempatkan ditengah-tengah pintu masuk gedung tempat koleksi peninggalan zaman kerajaan Majapahit. Dikatakan menarik karena lambang surya majapahit ada kemiripan dan kesamaan dengan lambang"dewate nawesangae" yang berkembang di Bali. Pahatan berbentuk lingkaran sinar matahari di bagi 8 sekat dan bagian paling dalam ada ruang berbentuk lingkaran kecil. Oleh para ahli pahatan surya majapahit tersebut disebut lambang dari kerajaan Majapahit. Lambang tersebut kerapkali ditemukan pada langit-langit candi, belakang arca, batu nisan, dan hiasan bangunan lainnya. Pada visualnya ditengah lingkaran yang dkelilingi oleh jurai-jurai sinar matahari yang terbagi 8 ruang berisi gambar dewa-dewa Hindu berpusat pada ruang lingkaran kecil berisi pahatan Dewa siwa. 
Penggunaan surya majapahit sebagai lambang kerajaan Majapahit ada 4 (empat) jenis, diantaranya: 1 jenis yang dipakai pada saat ibu kota dipindahkan ke Dahanapura, lambang dipakai saat pengungsian setelah diserang kerajaan demak, satu dipakai pada saat pelarian ke Barat, dan 1 (satu) dipaki pelarian ke arah Timu. Lambang Surya yang dipakai pelarian ke arah Timur termasuk Bali yang berakulturasi menjadi "lambang gambar "Dewate Nawesange”. Surya Majapahit sebagai lambang kerajaan Majapahit diperkirakan dibawa dan berakulturasi dengan ajaran "sekte" di Bali dengan ciri-ciri sebagai berikut.

a. Diluar lingkaran ada motif dengan jurai-jurai yang dikelompokan menjadi 8

b. Dalam lingkaran di bagi 8 ruang tampak masing-masing ruang ada figur dewa dan 1 ruang berpusat satu figur ditengah-tengah dalam bentuk bentuk perwujudan dewa.

c. Warna: abu-abu natural.

Pahatan Surya Majapahit tersebut di atas ditemukan pada langit-langit Grabhagriha (ruang suci), hiasan candi, pada belakang kepala arca, dan juga pada batu nisan di masa Majapahit. (ttps://wilwatiktamuseum.wordpress.com/ tanda-kebesaran-wilwatikta/lambang-kerajaan-wilwatikta-majapahit)

\section{b. Lambang "Dewata Nawesange"}

Lambang "dewata nawesange" sebagai manifestasi Ide Sang Hyang Widhi dengan berbagai bentuk, fungsi, makna, warna, tempat oleh umat Hindu. "Dewate Nawesange" adalah 9 (sembilan) dewa sebagi perlambangan kekuasaan dari sembilan penjuru mata angin seperti Dewa Brahma, Wisnu, Sambhu, Iswara, Maheswara, Rudra, Mahadewa, Sangkara, dan Siwa. (https://www.google.com/search?client=firefox-b-ab\&q=DEWE+NAWESANGE). Umat Hindu di Bali bentuk perwujudan "dewate nawesange" dibuat sangat kreatif ada dengan pahatan, lukisan, dan sate yang disebut dengan "sate gelar sange", dengan bahan daging babi namun tetap memiliki arti yang sama. Bentuk dan perwujudannya hampir sama dengan Surya Majapahit. Ciri-ciri gambar perlambangan "dewate nawesange" sebagai berikut.

a. Berbentuk lingkaran dan yang dibagi 8 ruang dan 1 ruang berpusat ditengah-tengah.

b. Pembagian 8 penjuru mata angin dan digambarkan figur 8 dewa serta 1 dewa ada ditengah.

c. Figur para dewa dibuat sesuai dengan filosofi warna, fungsi, tugas, dan tempat masing-masing.

\section{c. Fungsi dan Makna Lambang "Dewate Nawesange"}

Lambang "dewate nawesange" tidak hanya sekedar memiliki nilai estetik tetapi umat Hindu di Bali memiliki keyakinan pada masing-masing figur dewa ada pada 9 penjuru mata angin masing-masing mempunyai filosofi warna, tugas, fungsi dan makna seperti berikut.

a. Dewa Wisnu, ada di utara, berfungsi sebagai pemelihara, dengan warna hitam yang dimaknai ketakutan, ketakutan, kesucian, kesederhanaan, dan sebagainya. b. Dewa Brama, ada di selatan, berfungsi pencipta, warna merah bermakna sumber dari segala sumber, berani, cinta, api, darah, dan benih kehidupan.

c. Dewa Iswara, ada di Timur, dengan warna putih dimaknai matahari, pelebur, dan sumber kebangkitan.

d. Dewa Maha Dewa,ada di Barat, dengan warna kuning, dimaknai kemuliaan, keagungan fungsinya sebagai penjaga keseimbangan.

e. Dewa Sengkara,ada di Barat laut warna Hijau dimanai tumbuhan, kehidupan, kesuburan berfungsi sebagai penyatuan.

f. Dewe Sambu, ada Timur Laut, warna Biru dimkanai sebagai pemeliharaan, pemusnahan, kebebasan yang dimaknai hujan, banjir, dan kesedihan.

g. Dewa Mahesora, ada di Tenggara, warna Dadu fungsinya penjagaa keamanan di Tenggara, maknanya kesadaran, kebangkitan, dan kedamaian.

h. Dewe Rudra, ada di Barat daya, warna jingga fungsinya menjaga pembasmi kemurkaan, maknanya pengorbanan, penyerahan diri, bahaya dan kehidupan.

i. Dewe Siwa, ada di Tengah, warna campuran putih, merah, kuning, hitam, fungsi pelebur, pemusnah, maknanya kesucian.

\section{d. Lambang "Dewate Nawesange" Sebagai Reproduksi Budaya}

Reproduksi budaya dimaksudkan sebagai proses presentasi budaya baru yang masih munculkan budaya lokal yang didatangi oleh budaya luar.Proses reproduksi budaya terjadi dampak dari adanya mobilisasi sosial bisa dilakukan secara perorangan atau kelompok sehingga terjadi perubahan yang mewarnai produk budaya baru. Lambang "dewate nawesange" sebagai reproduksi budaya yang merupakan adanya presentasi budaya lokal dengan budaya luar. Hal tersebut merujuk pada sejarah sekte-sekte di Bali yang di tulis Goris (1974). Goris (1974:10-12) menyebut di abad ke IX telah berkembang dengan baik sekte-sekte di Bali seperti Siwa, Brahmna, Resi, Sora, Pasupata, Ganapatya, Bhairawa, Waisnawa, dan Sogatha. Diantara sekte-sekte tersebut yang paling berpengaruh adalah sekte Siwa Sidhanta. Kedatangan dan menetapnya tokoh-tokoh yang ahli pertanian, persenjataan, politik, ketata pemerintahan, ahli agama pasca kekuasaan kerajaan Majapahit mempercepat terjadinya perubahan pada tatanan kehidupan masyarakat di Bali. Secara dratis penguasa dari tanah Jawa melakukan banyak perubahan dengan cara menempatkan penguasa baru di daerah perkotaan termasuk mendatangkan para rsi. Kedatangan para rsi dengan tujuan untuk melakukan pembenahan pada kehidupan sekte-sekte dan keyakinan di Bali.

Sedikit bukti yang bisa dirujuk untuk membuktikan lambang "dewate nawesange" merupakan produksi budaya sebagai dampak dari adanya perpaduan sekte-sekte di Bali dengan konsep lambang Surya Majapahit yang kemungkinan besar di bawa oleh para rsi. Artefak berupa pahatan, gambar dari dua lambang tersebut sedikit bukti dengan 
Gambar lambang Surya Majapahit dan Gambar lambang "Dewate Nawesange” (Sumber: Internet, 2019)

\begin{tabular}{|c|c|c|c|}
\hline $\begin{array}{c}\text { Gambar lambang Surya } \\
\text { Majapahit }\end{array}$ & Identivikasi visual & $\begin{array}{c}\text { Gambar lambang "Dewate } \\
\text { Nawesange" }\end{array}$ & Identivikasi visual \\
\hline 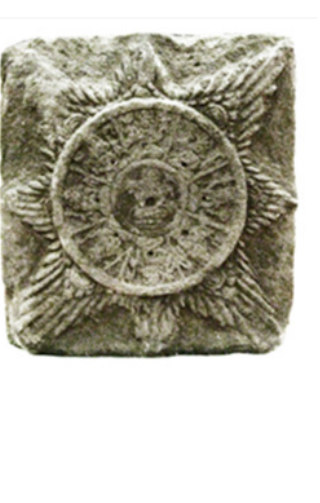 & $\begin{array}{l}\text { *dipahat di atas batu cadas } \\
\text { *ditengah dengan lingkaran } \\
\text { kecil dengan gambar figur } \\
\text { dewa } \\
\text { *lingkaran lebih besar dibagi } \\
8 \text { ruang masing-masing ada } \\
\text { pahata figur dewa } \\
\text { *8 bentuk jurai perlamban- } \\
\text { gan sinar matahari } \\
\text { *ditempatkan dilangit-langit } \\
\text { candi, dibelakang kepala } \\
\text { arca }\end{array}$ & & $\begin{array}{l}\text { *bisa dilukis, dipahat di atas } \\
\text { kayu, batu cadas } \\
\text { *lingkaran kecil ditengah-tenga } \\
\text { ada dewa siwa } \\
\text { *lingkaran lebih besar dibuat } \\
\text { bentuk kreatif ada } 8 \text { figur dewa } \\
\text { dengan identitas masing-masing } \\
\text { *jurai garis lambang sinar } \\
\text { matahari } \\
\text { *ditempatkan di prabe "pure" } \\
\text {,kober } \\
\text { *bersifat spritual, estetik }\end{array}$ \\
\hline
\end{tabular}

cara melakukan kajian dan analisi dengan teori semiotik dan intografi. Kajian artefak dua lambang tersebut dengan pendekatan ikonografi pahatan, gambar 9 figur dewa, binatang sebagai kendaraanya, dan jenis senjatanya menunjukan ada sebuah akulturasi atau perpaduan dari ajaran sekte yang sebelumnya telah berkembang di Bali dengan ajaran Agama Hindu yang dibawa oleh Rsi dari Majapahit. Pada posisi ditengah sebagai figur dikenal Siwa Sidhanta yang memiliki pengaruh besar yang pemujaan pada Tri Purusha (paraaa siwa, sada siwa, siwa) makanya ditempatkan ditengah-tengah. Dengan demikian konsep dewe nawesange merupakan produk budaya muncul karna adanya akulturasi yang dilakukan oleh tokoh-tokoh agama dari kerajaan Majapahit. Lambang dewe nawesange yang di sakralkan oleh umat Hindu di Bali sebagai produk budaya dengan tujuan pembenahan pada tatanan kehidupan sekte dan keyakinan di Bali. Secara etnografi, salahsatu nilai ajaran sekte waisnawe masih tercermin dalam kegiatan-kegiatan ritual masyarakat di Bali, seperti adanya pemujaan Dewi Sri sehabis panen padi dipandang sebagai dewi pemberi rejeki dan kemakmuran.

\section{e. Kajian Ikonografi Lambang Surya Majapahit dan Lambang "Dewate Nawesange"}

Kajian Ikonografi pada lambang "dewate nawesange" dengan maksud untuk membuktikan adanya akulturasi atau pengaruh dari lambang surya majapahit. Ikonografi dimaksudkan sebagai pengetahuan secara khusus mempelajari tentang intreprestasi isi gambar atau lambang. Penggunaan teori ini untuk menguraikan, mengidentifikasi, menggolongkan, menjelaskan objek perlambangan surya majapahit dan lambang "dewate nawesange" dengan tujuan untuk membuktikan telah terjadi akulturasi dari kedua lambang tersebut.

Melihat bentuk lambang surya majapahit kemudian dikomperkan dengan lambang "dewate nawesange" telah mengalami evolusi melalui kekuasaan, fase-fase yang sangat pasti dengan hegomoni yang dilakukan oleh to- koh rohani Hindu, Rsi dari Majapahit.Hal tersebut sejalan dengan pemikiran Edward Burnet Tylor (1832-1917) dan Lewis Henry Morgan ( 1818-1889) dalam teori evolusi deterministik semua pengendalian kebudayaan oleh manusia. Kedatangan orang-orang Majapahit pada saat ekspansi yang dipimpin oleh Patih Gajah Mada dan menempatkan tokoh-tokohnya untuk mengawasi kegiatan penduduk lokal pada saat itu sudah terjadi pertukaran sosial. Kemudian kedatangan pada gelombang kedua pada saat kerajaan Majapahit jatuh dan masuknya paham lain, para rohani Hin$\mathrm{du}$, Rsi ada yang memilih pergi ke arah timur menuju Bali, pada saat terjadi proses pertukaran sosial dengan pengetahuan orang-orang lokal dan aktivitas Agama Hindu lebih intensip. Diyakini pada proses tersebut terjadi pengorbanan, keuntungan yang saling mempengaruhi.

Membaca uraian visual gambar kedua lambang tersebut di atas peneliti berasumsi bahwa gambar lambang "dewate nawesange" yang berkembang di Bali merupakan sebuah perwujudan dari bentuk akulturasi kosep "sekte-sekte"di Bali berkembang sebelum masuk pengaruh Majapahit dengan lambang surya majapahit. Proses akulturasi diperkirakan terjadi pada masa kejayaan Majapahit, lebih sempurna ketika kerajaan Majapahit jatuh dan diketahui tokoh-tokoh rohani Hindu, para Rsi menyingkir dan menetap Bali.

\section{f. Akulturasi Sebagai Agen Perubahan}

Fenomena akan terjadi perubahan ketika kelompok-kelompok individu yang memiliki budaya berbeda terlibat dalam kontak langsung yang serasi dengan pola budaya asal dipastikan akan terjadi akulturasi (Herkovitz:1939). Akulturasi yang identik dengan agen perubahan dipahami sebagai perpaduan budaya yang menghasilkan budaya baru tanpa menghilangkan masing-masing identitas asli dari budaya tersebut. Lambang "dewate nawesange" sebagai reproduksi dari sekte-sete di Bali dengan lambang Surya Majapahit. Pada budaya baru sebagai bentuk reproduksi budaya seperti lambang "dewate nawesange" proses akul- 
turasi cukup panjang dan saling mempengaruhi namun unsur-unsur kedua budaya masih tercermin.

\section{METODE PENELITIAN}

Dantes, (2012: 50) menjelaskan penelitian deskriptif suatu penelitian yang berusaha mendeskripsikan suatu fenomena/peristiwa secara sistematis sesuai keadaan saat ini. Untuk mendapatkan data-data yang mendalam dilakukan penelitian historis, menggali fakta-fakta agar dapat susun suatu kumpulan mengenai peristiwa di masa lampau (2012: 50). Di samping itu juga menggunakan metode etnogafi untuk mengetahui pandangan dan pendapat masyarakat hindu di Bali tentang lambang'Dewa Nawesangae". Penelitian ini mengunanakan metode deskriptif analitik yaitu menguraikan makna-makna lambang Surya Majapahit, sekte-sekte, dan "Dewa Nawesange dengan cara mendeskripsikan melalui pengumpulan, penyusunan, dan penggalian data kemudian uraikan atau dijelaskan. Data diproleh langsung dari artefak, wawancara bersumber dari tokoh masyarakat yang mengetahui persoalan lambang"Dewa Nawesangae". Pengumpulan data dilakukan dengan teknik kombinasi (obsevasi, wawancara, kajian dokumen), dan pengolahan serta analisis data dimulai dari awal pengumpulan data, penyusunan proposal, display data, sampai pelaporan.

\section{ANALISIS DAN INTERPRESTASI DATA}

Analisis data mulai dari data pengumpulan, data reduksi, data display, data verification dan disimpulkan. Untuk lebih validnya data juga digunakan analisis triangulasi data, mengkomperkan lambang Surya Majapahit, ajaran "sekte-sekte", dan lambang "Dewa Nawesanga" dan trianggulasi sumber dengan teliti data yang diproleh dikroscekkan lagi ke sumber yang berkompoten. Hasil penelitian disajikan data masing-masing dengan cara dikelompokan sesuai karakteristik data, dimulai dari pendahuluan, analisis data, pemaparan hasil penelitian, kesimpulan dan laporan hasil temuan penelitian.

\section{SIMPULAN}

Pada saat serangan kerajaan Majapahit ke Bali sebelumnya di masayarakat telah berkembang beberapa aliran kepercayaan seperti "sekte-sekte" yang kemudian diketahui menjadi landasan perkembangan Agama Hindu. Jatuhnya kerajaan Majapahit akibat perebutan kekuasaan dan berkembang agama lain, tokoh rohani Hindu, Rsi merasa tidak nyaman tinggal di daerah kerajaan Majapahit dan memilih pergi menuju ke Bali, mereka ketahui Agama Hindu berkembang dengan baik. Kedatangan para rohani Hindu, Rsi dari Majapahit berdampak pada pembenahan sarana prasarana untuk mendukung aktivitas Agama Hindu di Bali, seperti bangunan "pure", konsep, filosofi, makna lambang "dewate nawesange" yang berefek pada akulturasi dari lambang surya majapahit.

\section{DAFTAR RUJUKAN}

Ardana, I Gusti, 2007, Pemberdyaan Kearipan Lokal Masyarakat Bali Dalam Menghadapai Budaya Global, Pustaka Tarukan Agung, Denpasar.

Ardika, Wayan. Pelestarian dan Pemanfaatan Tinggalan Arkeologi dalam mengembangkan pariwisata Budaya Bali. Denpasar: Program Studi Pariwisata Unud.

Ardika, Wayan dan Sutaba, Made. 1989. Dinamisme Kebudayaan Bali. Denpasar: PT Upada Sastra..

Beilharz, Peter. 2005. Teori-teori Sosial. Yogyakarta: Pustaka Pelajar.

Benedict, Ruth. 1966. Pola-pola Kebudayaan. Jakarta: Dian rakyat.

Dantes, Nyoman 2012, Metode Penelitian, Andi Yogykarta.

Dharsono, 2007, Estetika. Rekayasa Sains, Bandung.

Geertz, Clifford. 1992. Tafsir Kebudayaan, Refleksi Budaya. Yogyakarta: Kanisius.

Gede Jaman, 1999, Rerajahan dalam Kehidupan, Pramita Surabaya.

Koentjaraningrat. 1997. Manusia dan Kebudayaan Indonesia. Jakarta: Djambatan Jakarta.

Krisna Bayu Aji,2016, Di Balik Pesona dan sisi Kelam Majapahit, Araska Publisher Yogyakarta.

Lash, Scott, 2004, Sosiologi Post Modernisme, Kanisius, Yogyakarta.

Sastrodiwiryo, Soegianto, 2010, Perjalanan Danghyang Niratha, cetakan ke-5, BP, Denpasar.

Sartono, Kartodirdjo,dkk, 700 tahun Majapahit (12931993), Suatu Bunga Rampai, Edisi Keempat.

Sugiyono, 2011, Metode Penelitian Kombinasi, Alfabeta, Bandung

Ritzer, George, 2007, Teori Sosiologi Modern, Prenada Media Group.

Triguna Yudha I.B.G, 2003, Estetika Hindu dan Pembangunan Bali, Program Magister UNHI Denpasar. 


\section{Sumber Internet}

https://www.google.com/search?q=GAMBAR+SURYA+MAJAPAHIT $\&$ safe $=$ strict $\&$ client $=$ fire fox-b-ab\&tbm=isch\&source $=i$ iu $i c t x=1 \&$ fir $=H p 1$ rhdM 17 ttps://wilwatiktamuseum.wordpress.com/tanda-kebesaran-wilwatikta/lambang-kerajaan-wilwatikta-majapahit/ https://historia.id/kuno/articles/majapahit-menaklukkan-bali-DbeEG.

(https://historia.id/kuno/articles/penyebab-lain-keruntuhan-majapahit-DEZ1x).

(https://www.google.com/search?client=firefox-b-ab\&q=DEWE+NAWESANGE).

(https://history1978.wordpress.com/2010/04/07/agama-pada-masa-majapahit/ 